\title{
The Effect of Organizational Culture on Achievement Motivation of Teachers in SMP (Junior High School) Muhammadiyah in Medan
}

\section{Elfrianto}

University of Muhammadiyah Sumatera Utara (UMSU), Medan, Indonesia

\section{Abstract}

This study aims to find out the effect of organizational culture on achievement motivation of teachers in SMP (Junior High School) Muhammadiyah in Medan. This research is a quantitative study with ex post facto research design that is the variables studied are not controlled and manipulated by researchers, but the facts are expressed based on the measurement of symptoms that have been held or test what will happen. ). This research is carried out in SMP (junior high school) Muhammadiyah in Medan, which consisted of 13 schools. The results shows that Organizational culture has a direct positive effect on achievement motivation of teachers in SMP (junior high school) Muhammadiyah in Medan. In other words, the stronger the organizational culture, the higher the achievement motivation of teachers in SMP (junior high school) Muhammadiyah in Medan.

\author{
Keywords \\ Organizational culture; \\ achievement motivation: SMP \\ Muhammadiyah
}

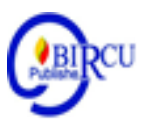

\section{Introduction}

Education is one of the efforts to build and improve the quality of human resources towards an era of globalization that is full of challenges, so that it is realized that education is very fundamental for every human being. Therefore educational activities cannot be ignored, especially in entering an era of increasingly fierce competition in the development of science and technology. Because education is a basic need, the world of education also requires planning to respond to the dynamics of changes that occur in the midst of society.

The results of Chapman and Adams research reveal the development of education in Asian countries is the effect of past education which emphasizes the quantity of students not on quality. Some policies related to the quality of education conclude: (1) the inability of staff (educators) to adequately accelerate the quality of the institution; (2) the government's commitment in improving the quality of education; (3) low level of students' learning abilities; and (4) the increasing demands of the community for graduates who master sophisticated equipment. The response to these changes must be done proactively and it is not enough just to be adaptive. Therefore, a new paradigm in education management is needed, namely a paradigm that leads to a focus on students in community-based education that leads to school quality assurance.

So that the quality of schools can be realized, then the continuous improvement of school performance is very important, because the nature of the school is not just maintaining its existence, but at the same time directing it to produce graduates in accordance with the expectations and demands of the community. To achieve these objectives, the participation and quality of competent teachers must be fulfilled. Morala's research results reveal that there are three strategic areas that can be done to improve the quality of the school environment, namely: (1) there is a need for future teaching by linking all educational policies leading to pedagogical improvement and quality improvement; (2) building a sense of responsibility and 
accountability in schools as a first step so that schools can decide for themselves what is best for their institution; and (3) continue to emphasize the role of the teacher as a pedagogical agent for conducting quality teaching.

In studies of organizational behavior, performance becomes an important factor in achieving organizational goals, thus placing performance as a measure of success in achieving organizational goals or calculating the outcome (countable outcome) or in terms of Rue Syars as the level of achievement of results or completion of organizational goals (the degree of accomplishment). According to Jackson and Mathis in the perspective of human resource development, performance can be seen from how effectively the resulting output is and how the organization's services are forwarded to its customers. Mondy and Noe stated that one of the goals of human resource management is to create activities that contribute to excellent organizational performance (superior organizational performance).

The teacher is a source human figure who occupies a position and plays an important role in education. When everyone is questioning the problem of education the figure of the teacher must be involved in the agenda of the discussion, especially those concerning formal education issues at school. According to Djamarah and Zain said that educators or teachers are professionals who are tasked with planning and implementing the learning process, assessing learning outcomes, conducting mentoring and training, and conducting research and community service. This cannot be denied because formal education institutions are the world of teacher's life, most of the time teachers are in school, the rest are at home and in the community.

The teacher is a very dominant and most important factor in formal education in general because for students teachers are often used as role models and even as selfidentification figures. In school teachers are elements that greatly influence the achievement of educational goals in addition to elements of students and other facilities. The success of the administration of education is very much determined by the readiness of the teacher in preparing his students through learning activities. However, the strategic position of teachers to improve the quality of education is strongly influenced by the quality of their performance. The task of the teacher seeks to influence, foster and develop students, and teachers are required to have the basic skills needed as educators, mentors and instructors and these abilities are reflected in teacher competence.

On the other hand teacher performance is also questioned when discussing the problem of improving the quality of education. The controversy between the ideal conditions that must be lived by the teacher in accordance with the expectations of the Law on the National Education System No. 20 of 2003 with the reality that occurred in the field is something that is necessary and proper to be examined in depth about the factors causing the emergence of the dilemma, because only by understanding the factors that affect teacher performance can alternative solutions be sought so that these factors do not become obstacles to improving performance teachers but are able to improve and encourage teacher performance towards a better cause.

\section{Review of Literature}

\subsection{Teacher Perfomance}

Performance is defined as the appearance, results or work performance. Another word for performance is achievement. This is in accordance with the opinion of Bernardin and Russel who say achievement is a record of the results obtained from certain job functions or 
certain activities during a certain period of time. Armstrong explained performance related to work and the results achieved from the job, namely performance is the output or work results achieved by a person or organization in accordance with work standards. Meanwhile, Colquitt, LePine, and Wesson stated that performance is the business value or work of teachers who have contributed both positively and negatively to organizational goals.

Thus the term performance has an understanding of the existence of an action or activity displayed by someone in carrying out certain tasks and activities. A person's performance will appear in daily work situations and conditions. The activities carried out by someone in carrying out their work describe how someone tries to achieve the goals set. Stiffler stated that organizational performance is the result of work in quantity and quality achieved by the organization. Timpe argues that performance is the accumulation of three interrelated elements namely ability, effort, and the characteristics of external circumstances. Correspondingly, Robbins and Coulter define performance theory as a product of the ability, motivation, and environment functions. This means that performance is expressed as a product, namely the work products of people or institutions or organizations.

Although there is no single factor that affects performance, according to Peters and Waterman in Sagala in the results of their study concluded there are seven contributing factors to organizational effectiveness describing organizational performance known as 7 planning (framework), namely the framework as follows: (1) strategy, is a coherent set of actions as a pattern of the company's response to its environment in a long-term plan with regard to the allocation and use of available resources to achieve goals; (2) structure, is an arrangement that illustrates the relationship between the division of tasks and responsibilities; (3) system, is all processes and procedures in a regular and integrated order; (4) staff, are people involved in managing the organization; (5) style, is real evidence that is shown by management that describes what is considered important; (6) expertise, is the capacity and ability of the management or people who are in the organization; and (7) the values of togetherness, are basic values that state a goal in determining the image of the organization that is jointly developed by people in the organization. Zainun defines performance as a work that can be achieved by a person or group of people in an organization in accordance with their respective authorities and responsibilities in order to achieve the objectives of the organization concerned legally, not violating the law and in accordance with morals and ethics.

Colquitt, LePine, and Wesson formulate organizational behavior with an integration model that explains that performance and commitment are influenced by a variety of variables in general, namely factors: (1) organizational mechanism; (2) individual mechanisms; and (3) individual appearance. In the integration model it is assumed that teachers have two main goals at work, namely: they do a good job and remain members of the organization as long as they are committed. Likewise, most managers have two main goals for their teachers: to maximize teacher performance and to ensure that teachers remain committed to the company for a long time. The integration model of organizational behavior is described as follows. 


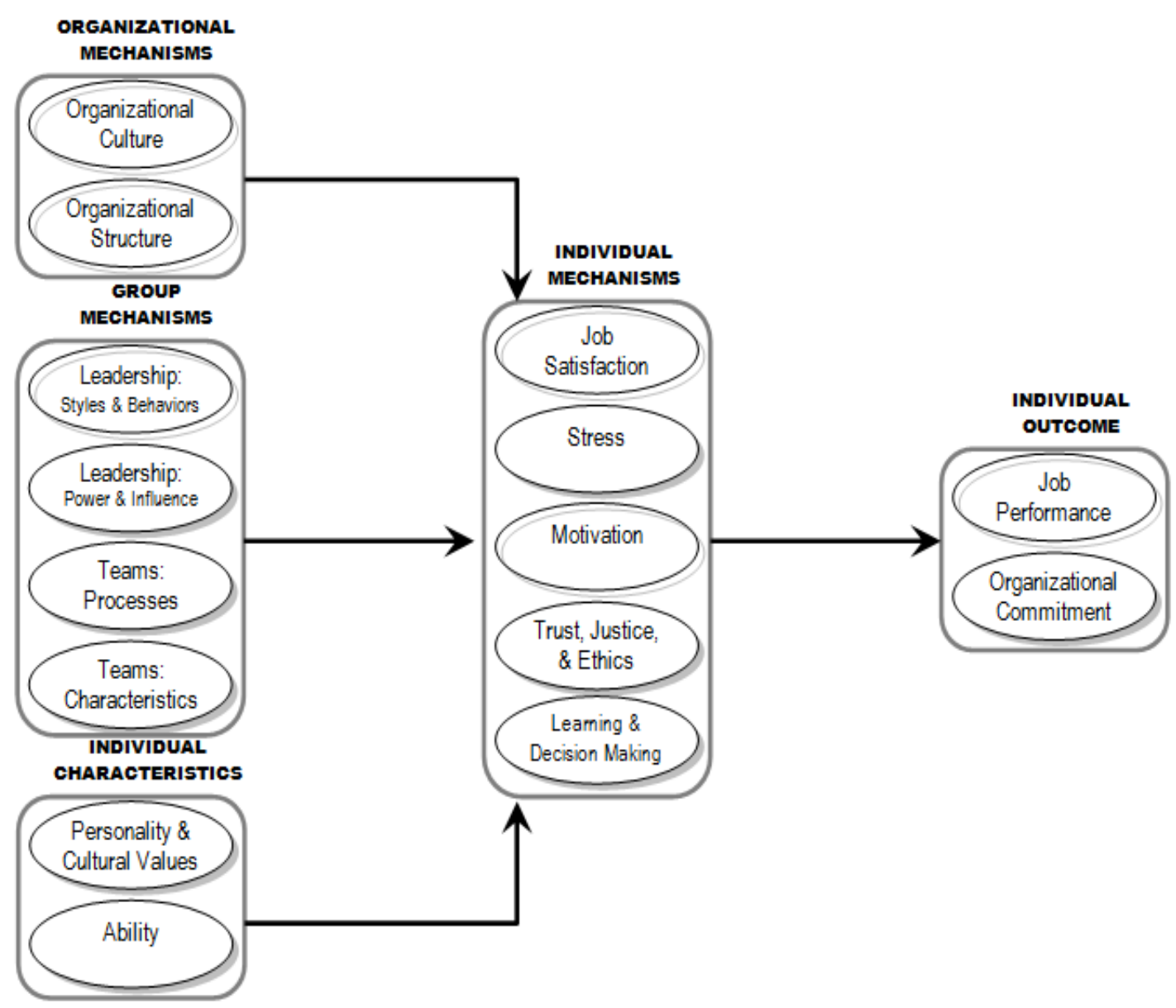

Figure 1. Integration Model of Organizational Behavior (Colquitt, LePine, and Wesson 2009)

Based on the model explained that the individual mechanism describes a number of individual mechanism processes that directly affect the performance and commitment of the organization. This includes job satisfaction, which captures how teachers feel when thinking about their work and doing their capacity. This model also includes motivation, which captures the energetic forces that drive the work effort of teachers. Justice and ethics reflect the extent to which teachers feel that their organizations operate with fairness, honesty, and integrity. The final individual mechanism is displayed in the learning and decision making model, which is related to how teachers obtain work knowledge and how they use that knowledge to make accurate assessments on work.

\subsection{Organizational Culture}

The word Culture comes from the Latin language (with the root word "Calo" which means working the land, cultivating the land or maintaining the fields and looking after livestock.) humans who consciously or not, can be accepted as a civilized behavior.

Organizational culture is a term that gets a lot of attention from experts about the organization, this is because the role is very important and can provide an in-depth understanding of organizational life. According to Rivai and Silvianabudaya are a number of important understandings such as norms, values, attitudes, and beliefs that are shared by 
members of the organization. Meanwhile, Robbins states that organizational culture is a system of shared meanings shared by members that distinguishes the organization from other organizations. This system of shared meaning, when examined more closely is a set of main characteristics that the organization upholds. Kreitner and Kinicki define that organizational culture is an organizational glue that binds members of the organization through values that are adhered to, symbolic tools, and social ideals to be achieved.

A well-developed organizational culture can move people in an organization to carry out work activities. Unconsciously, every person in an organization learns the culture prevailing in his organization. Hofstede argues that organizational culture has five main characteristics, namely: (a) organizational culture is an integral and interrelated unit, (b) organizational culture is a historical reflection of the organization concerned, (c) organizational culture is related to matters learned by anthropologists, such as rituals, symbols, stories, and figures, (d) organizational culture is socially constructed, in the sense that organizational culture is born from a shared consensus of the group of people who founded the organization, and (e) organizational culture is difficult to change . In other words, good organizational culture has full power and influence on individuals and their performance even on the work environment.

Organizational culture can be said to be good if it is able to move all personal consciously and is able to contribute to optimal work effectiveness and productivity. When associated with the culture that exists in schools, then organizational culture is a characteristic that exists in the school environment. Suharsaputra stated that school culture is a personality that distinguishes one school from another, how all members of the school organization's role in carrying out their duties depends on the beliefs, values and norms that are part of the school's culture. Strong culture is the core values of the organization held firmly and upheld together. The more members accept core values and the greater their commitment to those values and the stronger the culture. A strong culture shows a high agreement between members regarding what the organization believes.

A strong organizational culture will help the organization to provide certainty for all individuals in the organization to develop together and maintain their existence as long as possible. While a weak organizational culture will negatively affect the organization because it will give the wrong direction to the employees so that the organization becomes ineffective and less competitive.

According to Kotter and Hesket in Purba, in theory about the relationship between company culture and performance, the so-called Theory I is that a strong culture can improve company performance. Through a strong culture, organizations can foster commitment, loyalty and performance from employees. Cultural power influences performance which consists of three ideas, namely: First, the unification of goals. If there is a strong culture in an organization, the employee or employee tends to take the same direction. Second, creating motivation, commitment, loyalty to employees or employees. Third, provide the necessary structure or control without having to rely on formal bureaucracy that can emphasize the growth of motivation and innovation.

Some important things that must be considered to strengthen organizational culture, according to Suharsaputra, stated the following steps:

a. Employee selection. In selecting employees, consideration must be given to the suitability between the aspirations of the prospective employee and the culture of the organization, whether the candidate can accept the culture and adapt or it will weaken the culture formed. 
b. Employee placement. The goal is that employees can respect their colleagues and the norms and values that apply. Appropriate employee placement is expected to form a sense of unity among employees.

c. Deepening of the field of work. Every employee needs to explore the field of work in order to fully understand what his duties and responsibilities are.

d. Performance appraisal and awarding. Performance appraisal and award are intended so that employees who have carried out their work in accordance with the provisions are more motivated to work well in the future. The form of appreciation is adjusted to the situation at hand.

e. Spreading stories and news. The spread of stories and news about various matters related to organizational culture aims to emphasize the importance of moral values for every employee.

f. Recognition of performance and promotion of position. Recognition and promotion is given to employees who have carried out their duties and obligations, carry out their responsibilities optimally and set an example for other employees. In providing recognition and promotion of this position, the company must have standard and transparent criteria so that it can be applied consistently to all employees.

A strong organizational culture can illustrate how values and norms are strictly applied. This means that cultural strength shows the extent to which teachers behave with influence or are determined by assumptions, values and norms prevailing in schools. So the strength of organizational culture is related to the influence of values and norms on actual behavior that also shows social control and compliance with these values and norms.

Cultural values that are instilled by the leadership will be able to increase willingness, honesty, loyalty, and pride and further create work effectiveness. By strengthening the organizational culture, it will be realized if all components within the organization support one another, starting from staff, teachers to the leadership level. Organizational culture in schools is the dominant values supported by schools or philosophies that guide school policies towards all elements and components of schools including educational stakeholders, such as how to carry out work in schools and the basic assumptions or beliefs held by school personnel. It can be understood that school culture refers to a system of values, beliefs and norms that are collectively accepted, and implemented with full awareness as a natural behavior, formed by an environment that creates a common understanding among all elements and personnel of the school whether the headmaster, teachers, staff, students and if necessary form the same community opinion as the school.

Organizational culture is often portrayed in a shared sense. Patterns of beliefs, symbols, rituals and myths that develop over time and function as the glue that holds the organization together. Luthans stated that organizational culture has a number of important characteristics, including: (a) observed behavioral rules. When members of an organization interact with each other, they use common language, terms and rituals related to respect and ways of behaving, (b) norms. It is a standard of behavior, including guidelines on how much work is done, which in many companies becomes "don't do too much; not too little ", (c) dominant value. The organization supports and expects participants to share key values. Examples are high product quality, slight absence, and high efficiency, (d) philosophy. There are policies that shape organizational beliefs about how employees and or customers are treated, (e) rules. There are strict guidelines relating to the achievement of the company. Newcomers must learn existing techniques and procedures to be accepted as members of a developing group, and (f) Organizational climate. It is the overall "feeling" conveyed by the new physical 
arrangements, the way participants interact, and the way members of the organization relate to customers and individuals from outside.

\subsection{Achievement Motivation}

Motivation comes from the Latin word movere which means encouragement or move. Motivation, according to McShane and Glinow, is an impulse in a person that affects the direction, intensity, and perseverance of behavior. Motivation according to Slocum and Hellrigel is the urge to work or within a person which causes that person to behave in a certain way.

In contrast to Lussier's opinion that motivation is the willingness to achieve organizational goals. According to Robbins and Coulter motivation is the process of willingness to do high-level effort to achieve organizational goals, which is conditioned by the ability of the business to satisfy the needs of a number of individuals. Meanwhile, according Sedarmayanti said motivation as a whole process of giving work motives to subordinates in such a way that they want to work sincerely for the achievement of organizational goals effectively and efficiently. Concretely, motivation can be limited as "the process of giving motives (driving) to work for subordinates in such a way that they are willing to work sincerely for the achievement of organizational goals efficiently". Thus, motivation is the granting of enthusiasm to work for members of the organization and by providing motivation is intended to provide stimulant power to members of the organization so that they work with all their power and efforts. Chung and Megginson in Usman classify motivation theory in detail into two, namely: content motivation theory and process motivation theory. The focus of the study of each motivational theory is as follows Table 1.

Table 1. Focus of Motivation Theory

\begin{tabular}{|c|l|l|}
\hline $\begin{array}{c}\text { Motivation } \\
\text { Theory }\end{array}$ & $\begin{array}{c}\text { Content: } \\
\text { Maslow, Alderfer, Gregor, } \\
\text { Herzberg, McClelland }\end{array}$ & $\begin{array}{c}\text { Process: } \\
\text { Lewin-Vrom, Adams, } \\
\text { Skinner, Locke }\end{array}$ \\
\hline Focus & $\begin{array}{l}\text { At the cause of the behavior } \\
\text { occurs and stops }\end{array}$ & $\begin{array}{l}\text { How behavior begins } \\
\text { and is carried out }\end{array}$ \\
\hline
\end{tabular}

Based on these classifications, content theory focuses on what causes behaviors to occur and stop, answers focus on: (a) the needs, desires, or impulses that drive activities, and (b) the relationship of teachers with external factors and internal causes them to carry out activities. Where this model is described as follows.

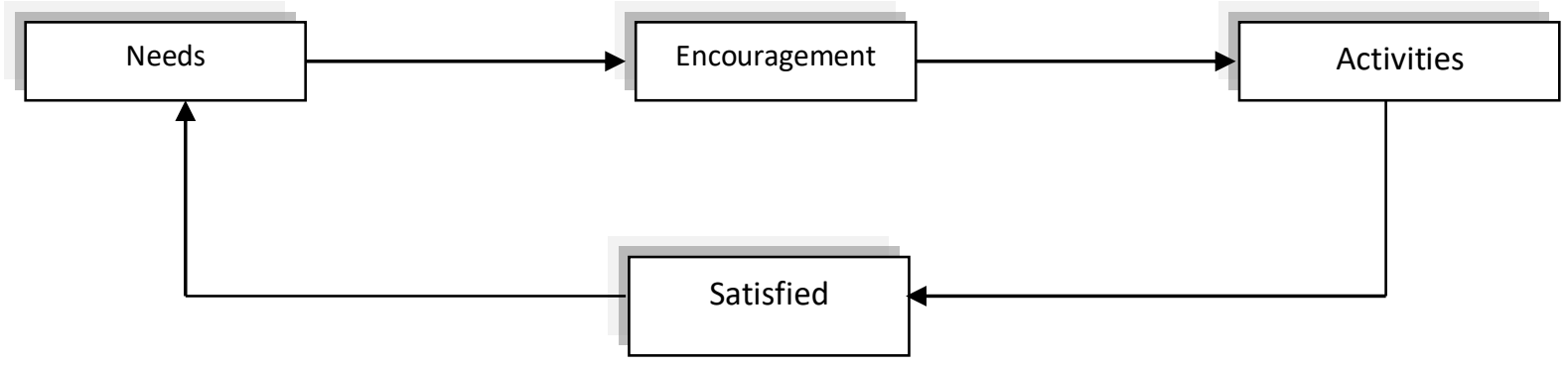

Figure 2. Process of Content Motivation (Stoner, 2000) 
Every individual has the desire to be able to do something. That desire becomes a driving force from within to carry out certain activities in order to achieve a goal. Changes in a person characterized by the emergence of feeling, and preceded by a response to the existence of goals is motivation. Therefore, motivation is related to the level of effort done by someone to achieve a goal, so motivation is closely related to job satisfaction and commitment.

\subsection{Effects of Organizational Culture on Achievement Motivation}

Organizational culture is the beliefs, attitudes and daily behavior of every teacher in carrying out their duties in school according to school regulations. While achievement motivation is an encouragement obtained by someone to perform better than the work of others.

Organizational culture has a very strategic role to encourage and improve the effectiveness of organizational performance, both in the short and long term. Organizational culture acts as a social glue that binds fellow members of the organization together in a common vision and goals. Organizational culture as a system of values that are believed by all members of the organization and are studied, applied and developed on an ongoing basis, function as an adhesive, and can be used as a reference to behave in the organization to achieve company goals that have been set. Understanding, that organizational culture such as at school is a value that determines the direction of behavior of members in the organization. If the value becomes a shared value, then a common perception of behavior is formed in accordance with the character of the organization.

Organizational culture is a pattern of basic assumptions to act, determine, or develop organizational members in overcoming problems by adapting them from the outside and integrating into the organization, where employees can work carefully, and also benefit new employees as a basis for correction of their perceptions, thoughts, and feelings in relationships overcome problems. Culture has a strong impact on organizations

Each teacher basically has different characteristics and interests. This difference can sometimes cause negative effects for the organization / school if not managed properly. Therefore, schools need to have shared values which do not reflect individual interests or character. These values can be reflected in the daily behavior of teachers at school. With the shared values, the school's interests are above the individual's interests. Nevertheless, shared values must be able to facilitate individual interests, so that every teacher in the organization / school will be motivated to do the best for the organization / school. Based on these descriptions, it is suspected that organizational culture has a direct positive effect on teacher achievement motivation.

\section{Research Method}

This research is a quantitative study with ex post facto research design that is the variables studied are not controlled and manipulated by researchers, but the facts are expressed based on the measurement of symptoms that have been held or test what will happen. Bungin said if the research aims to expose ongoing events, this is called expost facto research. The research method used was a survey method and to analyze one variable with another variable used path analysis. Path analysis requires the requirement of a significant linear regression form between variables. According to Riduwan, path analysis is used to analyze the pattern of relationships between variables with the aim to determine the effect of 
the independent (exogenous) variables on the dependent variable (endogenous). This research is carried out in SMP (junior high school) Muhammadiyah in Medan, with the serial number of schools based on the serial number in North Sumatera. The study is conducted from March 2015 and ended in January 2016. The population of this study were all teachers of the Muhammadiyah Middle School in Medan, which totaled 297 teachers in 13 schools.

Table 2. Research Population

\begin{tabular}{|c|c|c|}
\hline No & School & $\begin{array}{c}\text { Total number } \\
\text { of teachers }\end{array}$ \\
\hline 1 & SMP Muhammadiyah 1 Medan & 43 \\
\hline 2 & SMP Muhammadiyah 2 Medan & 27 \\
\hline 3 & SMP Muhammadiyah 3 Medan & 28 \\
\hline 4 & SMP Muhammadiyah 4 Medan & 18 \\
\hline 5 & SMP Muhammadiyah 5 Medan & 20 \\
\hline 6 & SMP Muhammadiyah 6 Medan & 20 \\
\hline 7 & SMP Muhammadiyah 7 Medan & 23 \\
\hline 8 & SMP Muhammadiyah 8 Medan & 20 \\
\hline 9 & SMP Muhammadiyah 9 Medan & 19 \\
\hline 10 & SMP Muhammadiyah 33 Medan & 18 \\
\hline 11 & SMP Muhammadiyah 45 Medan & 18 \\
\hline 12 & SMP Muhammadiyah 48 Medan & 18 \\
\hline 13 & SMP Muhammadiyah 57 Medan & 25 \\
\hline & Total & 297 \\
\hline
\end{tabular}

\section{Discussion}

\subsection{Effects of Organizational Culture on Achievement Motivation}

The frequency distribution of organizational culture variable data is as shown in Table 3.

Table 3. Frequency Distribution of Organizational Culture Data

\begin{tabular}{|c|c|c|c|}
\hline No & Interval Class & $\begin{array}{c}\text { Absolute } \\
\text { Frequency }\end{array}$ & $\begin{array}{c}\text { Relative } \\
\text { Percentage (\%) }\end{array}$ \\
\hline 1 & $84-94$ & 17 & 9,94 \\
2 & $95-105$ & 19 & 11,11 \\
3 & $106-116$ & 23 & 13,45 \\
4 & $117-127$ & 23 & 13,45 \\
5 & $128-138$ & 24 & 14,04 \\
6 & $139-149$ & 25 & 14,62 \\
7 & $150-160$ & 24 & 14,04 \\
8 & $161-171$ & 13 & 7,60 \\
9 & $172-182$ & 3 & 1,75 \\
\hline \multicolumn{2}{r}{} & 171 & 100,00 \\
\hline
\end{tabular}

Based on Table 3 it can be explained that the percentage of Organizational Culture scores are at an average score of $14.04 \%$ (24 respondents), below the average score of $47.95 \%$ ( 82 respondents), and $38.01 \%$ (65 respondents ) is above average. Furthermore, it can 
be described in a histogram of the frequency distribution of Organizational Culture scores as shown in Figure 3.

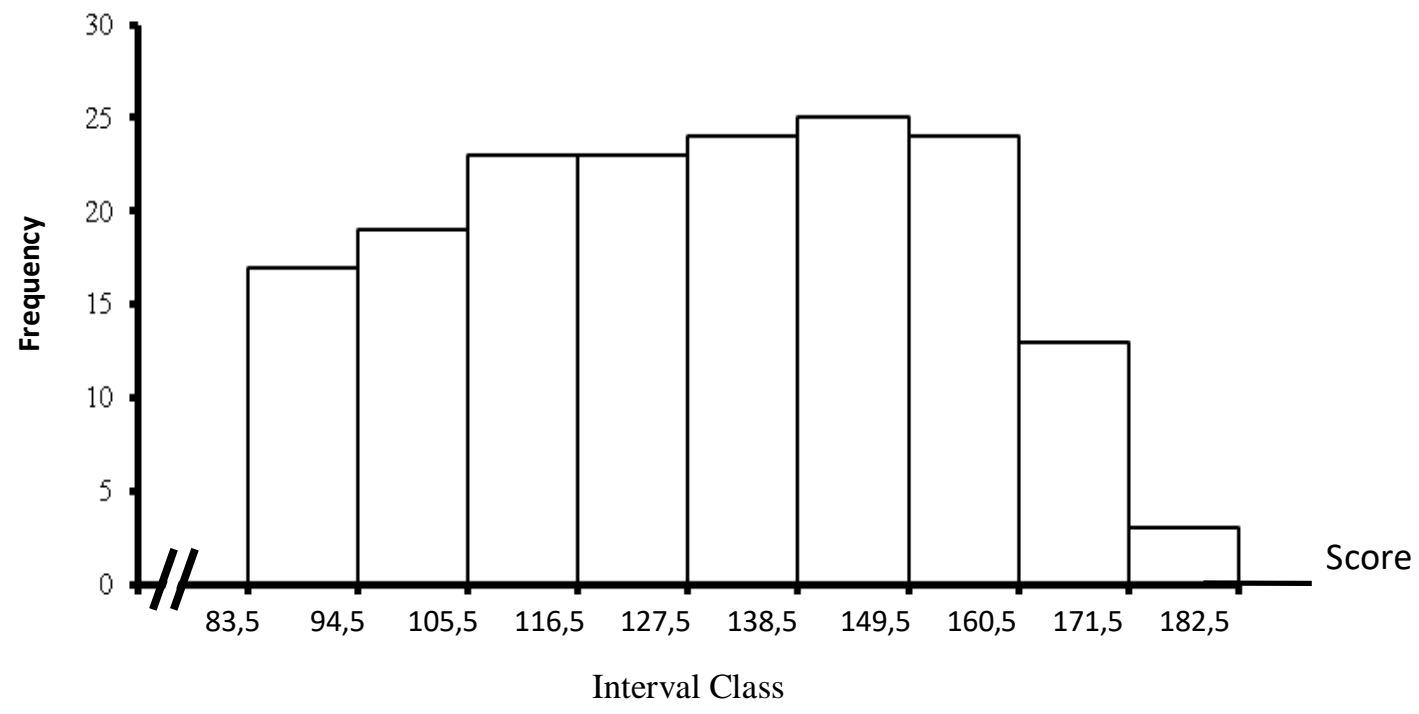

Figure 3. Histogram Scores of Organizational Culture Variables

\subsection{Description of Achievement Motivation Variable Data}

Frequency distribution of Achievement Motivation variable data as shown in Table 4.

Table 4. Frequency Distribution of Achievement Motivation Data

\begin{tabular}{|c|c|c|c|}
\hline No & Interval Class & $\begin{array}{c}\text { Absolute } \\
\text { Frequency }\end{array}$ & $\begin{array}{c}\text { Relative } \\
\text { Percentage (\%) }\end{array}$ \\
\hline 1 & $70-83$ & 3 & 1,75 \\
2 & $84-97$ & 6 & 3,51 \\
3 & $98-111$ & 10 & 5,85 \\
4 & $112-125$ & 31 & 18,13 \\
5 & $126-139$ & 40 & 23,39 \\
6 & $140-153$ & 46 & 26,90 \\
7 & $154-167$ & 25 & 14,62 \\
8 & $168-181$ & 7 & 4,09 \\
9 & $182-195$ & 3 & 1,75 \\
\hline \multicolumn{2}{|c|}{ Total } & 171 & 100,00 \\
\hline
\end{tabular}

Based on Table 4 it can be explained that the percentage of achievement motivation scores are at an average score of $23.39 \%$ (40 respondents), below the average score of $29.24 \%$ (50 respondents), and $47.37 \%$ ( 81 respondents ) is above average. Furthermore, it can be illustrated in a histogram of the frequency distribution of achievement motivation scores as shown in Figure 4. 


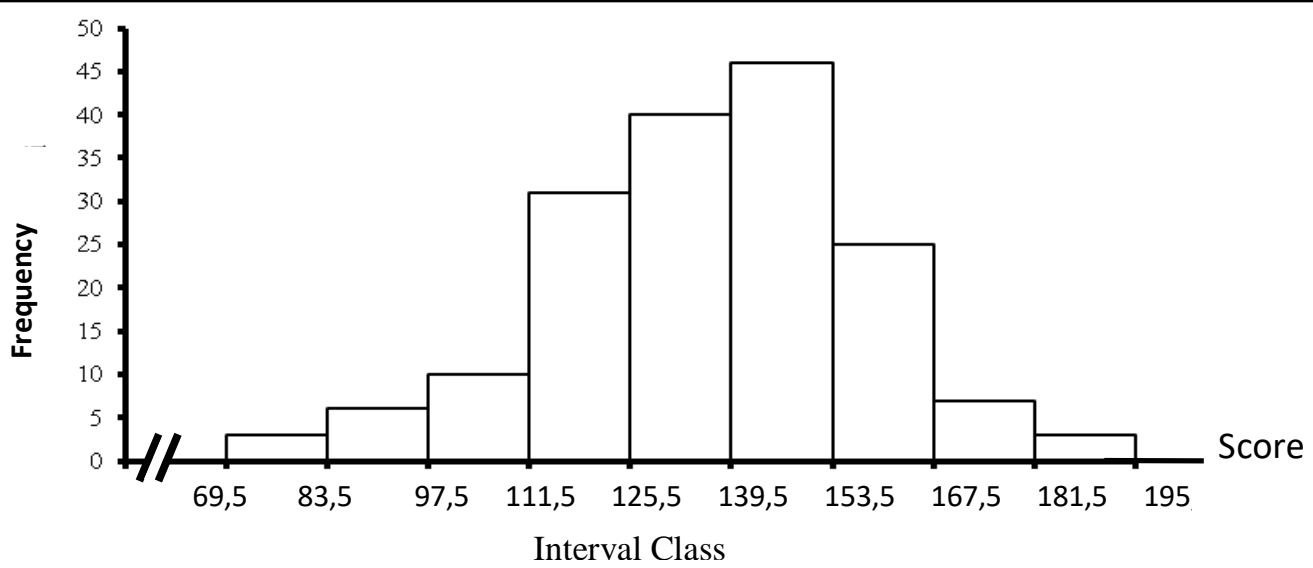

Figure 4. Histogram of Achievement Motivation Variable Scores

\subsection{Description of Teacher Performance Variable Data}

The frequency distribution of teacher performance variable data is as shown in Table 5.

Table 5. Frequency Distribution of Teacher Performance Data Scores

\begin{tabular}{|c|c|c|c|}
\hline No & Interval Class & $\begin{array}{c}\text { Absolute } \\
\text { Frequency }\end{array}$ & $\begin{array}{c}\text { Relative } \\
\text { Percentage }(\%)\end{array}$ \\
\hline 1 & $101-106$ & 3 & 1,75 \\
\hline 2 & $107-112$ & 10 & 5,85 \\
\hline 3 & $113-118$ & 18 & 10,53 \\
\hline 4 & $119-124$ & 21 & 12,28 \\
\hline 5 & $125-130$ & 27 & 15,79 \\
\hline 6 & $131-136$ & 29 & 16,96 \\
\hline 7 & $137-142$ & 34 & 19,88 \\
\hline 8 & $143-148$ & 17 & 9,94 \\
\hline 9 & $149-154$ & 12 & 7,02 \\
\hline \multicolumn{2}{|r|}{ Total } & 171 & 100,00 \\
\hline
\end{tabular}

Based on Table 4. and Table 5 it can be seen that the highest score is 151 , the lowest score is 101 , the mean is 130.90 , the median is 131 , the mode is 135 , the standard deviation is 11.95, while the ideal highest score is 200 , the lowest score ideal of 50 , ideal mean of 125 , and ideal SD of 25. So, the mean of research findings (observation) is greater than the ideal mean, which is: $130.90>125$, so the teacher's performance is expressed in the good category. Furthermore, a histogram of the frequency distribution of teacher performance scores can be drawn as shown in Figure 5.

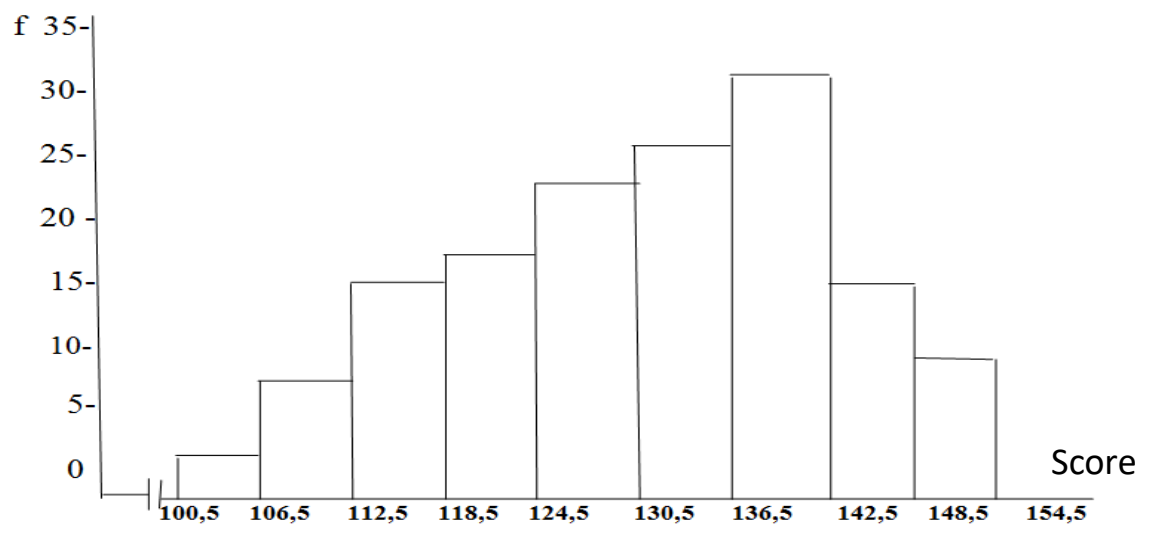




\subsection{Hypothesis}

The hypothesis proposed is:

Ha: $\rho 43 \leq 0$; There is no direct influence on organizational culture achievement motivation of Muhammadiyah Middle School teachers in Medan City

Ha: $\rho 43>0$; There is a direct influence of organizational culture on motivation achievers of Muhammadiyah Middle School teachers in Medan City

Test criteria: reject Ho if $\mathrm{t}>\mathrm{t}_{\text {table }}$ at $\alpha 0.05$ and $\mathrm{dk}=169$ is 1.645 . From the calculations obtained if $t_{\text {count }}>t_{\text {table }}$ is $3.124>1.645$ so that Ho is rejected. The results of testing the research hypothesis is $\rho 43>0$, meaning that the path coefficient of organizational culture toward achievement motivation is 0.219 significant at $\alpha=0.05$ level. In other words, the results of the analysis provide information that organizational culture has a direct effect on organizational culture on the achievement motivation of teachers in Junior High School (SMP) Muhammadiyah in Medan.

\subsection{Organizational Culture Directly Influences Achievement Motivation}

The results of this study indicate that the magnitude of the direct influence of organizational culture on achievement motivation is $4.79 \%$. This illustrates that organizational culture influences teacher achievement motivation. The suboptimal organizational culture can be seen from the low motivation of teachers in school achievement.

Furthermore, the results of this study are in line with the results of research by Koesmono (2005) and Widodo (2011) that organizational culture influences employee achievement motivation. The findings of this study support the theory used as a basis for proposing a theoretical model of research variables, the Colquitt Theory which explains that organizational culture directly influences one's motivation.

Organizational culture is the beliefs, attitudes and daily behavior of every teacher in carrying out their duties in school according to school regulations. Each teacher basically has different characteristics and interests. This difference can sometimes cause negative effects for the organization / school if not managed properly. Therefore, schools need to have shared values that do not separate individual interests or character. These values can be reflected in the daily behavior of teachers at school. With the shared values, the school's interests are above the individual's interests. Nevertheless, shared values must be able to facilitate individual interests, so that every teacher in the organization / school will be motivated to do the best for the organization / school. In addition, efforts that can be made to improve teacher achievement motivation through organizational culture are by increasing all dimensions of organizational culture, namely increasing innovation and risk taking, increasing attention to details, increasing orientation towards results, increasing orientation towards people, increasing towards team orientation, increased aggressiveness, and increased stability.

\section{Conclusion}

Organizational culture has a direct positive effect on achievement motivation of teachers in SMP (junior high school) Muhammadiyah in Medan. In other words, the stronger the organizational culture, the higher the achievement motivation of teachers in SMP (junior high school) Muhammadiyah in Medan. With the acceptance of the third research hypothesis that there is a direct influence between organizational culture on the achievement motivation of teachers in SMP (junior high school) Muhammadiyah in Medan, it is necessary to improve 
the organizational culture to optimize the achievement motivation of teachers in SMP (junior high school) Muhammadiyah in Medan. To improve organizational culture, efforts can be made to provide opportunities for all teachers to innovate in their work. With the opportunities given by all teachers to other teachers at work can motivate teachers to continue to work well. Besides that, another thing that needs to be improved in growing work motivation is to form a work team at school. With the culture of working in teams (together) every teacher will be motivated to provide the best for the school. This effort is expected to be able to improve the development of the school's organizational culture in a better direction in supporting increased teacher work motivation.

\section{References}

Amstrong, Michael. 2000. Performance Management. Key Strategies and Practice Guidelines. USA: Kogan Page.

Ancok, Djamaludin. 2002. Teknik Penyusunan Skala Pengukur. Yogyakarta: Pusat Studi Kependudukan dan Kebijakan UGM.

Bernardin, C.I dan Russel. 1993. Merencanakan Perubahan. Terjemahan. Jakarta: Intermedia.

Burhan, Bungin. 2008. Metode Penelitian Kuantitatif. Jakarta: Kencana Prenada Media Group.

Burhanuddin. 1999. Organisasi Masa Kini. Jakarta: Grafindo Persada

Cheong, Cheng Y., Tam W. Ming, danTsui K. Tung. 2002. "New Conceptions of Teacher Effectiveness and Teacher Education in the New Century". Hong Kong Teachers' Centre Journal, Vol. 1, Spring 2002, pp. 1-19.

Coleman, Marianne dan Derek Glover. 2010. Educational Leadership and Management. New York: McGraw Hill.

Colquitt, Jason A., Jeffery A. LePine, dan Michael J. Wesson. 2009. Organizational Behavior: Improving Performance and Commitment in the Workplace. New York: McGraw Hill.

Dharma, Agus. 1992. Perilaku Organisasi. Jakarta: Erlangga.

Hunseker. 2002. Trainning in Management Skill. New Jersey: Prentice Hill.

Muijs, Daniel dan David Reynolds. 2008. Effective Teaching: Teoridan Aplikasi. Terjemahan. Yogyakarta: Pustaka Pelajar.

Slocum, John W. dan Don Hellriegel. 2009. Principles of Organizational Behavior. Canada: South Western.

Soetjipto dan Basori Mukti. 1993. Administrasi Pendidikan. Jakarta: Depdikbud

Sotjipto dan Raflis Kosasi. 2009. Profesi Keguruan. Jakarta: Rineka Cipta.

Stiffler, Mark A. 2006. Performance: Creating the Performance Drive Organization. New Jersey: John Weley and Son Inc.

Stroey, John. 2004. Leaderships in Organization. London: Routledge

Sudijono, Anas. 2001. Pengantar Statistik Pendidikan. Jakarta: Raja Grafindo Pers.

Sudjana. 2002. Metode Statistika. Bandung: Tarsito.

Sugiyono. 2008. Metode Penelitian Pendidikan, Pendekatan Kuantitatif, Kualitatif, dan $R \& D$. Bandung: Alfabeta.

Suhardan, Dadan. 2010. Supervisi Profesional (Layanan Dalam Meningkatkan Mutu Pembelajaran di Era Otonomi Daerah). Bandung: Alfabeta.

Suharsaputra, Uhar. 2010. Administrasi Pendidikan. Bandung: Refika Aditama. 
Sumarno. 2011. "Implementasi Manajemen Kepemimpinan Kepala Sekolah Dalam Meningkatkan Kinerja Di SMPMuhammadiyah 3 Medan Selayang”. Thesis, Medan: Pascasarjana IAIN-SU.

Suryabrata, Sumadi. 2002. Pengembangan Alat Ukur Psikologis. Yogyakarta: Andi Offset.

Sutisna, Oteng. 1993. Administrasi Pendidikan Dasar Teoritis Untuk Praktek Profesional. Bandung: Alfabeta.

Timpe, Dale E. 1992. Kinerja: Seri Ilmudan Seri Manajemen Bisnis. Jakarta: Pustaka Ilmu.

Yaniawati, Poppy. 2010. E-Learning Alternatif Pembelajaran Kontemporer. Bandung: Arfino Raya.

Yulk, Gary. 2001. Kepemimpinan Dalam Organisasi. Edisi Kelima. Terjemahan. Jakarta: Indeks.

Zuhdi, Muhammad. 2007. "Sikap Profesional Guru Dalam Meningkatkan Mutu Pendidikan". Jurnal Ilmu Pendidikan, Vol 2 No 3.Desember 2007. UNJ 